\section{Risk Factors for Invasive Bacterial Infection and Mortality in Febrile Neutropenic Children}

\author{
Febril Nötropenik Çocuk Hastalarda Gelişen Invazif \\ Bakteriyel Enfeksiyon ve Buna Bağlı Gelişen \\ Mortalitede Risk Faktörleri
}

\section{Belgin Gülhan ๑ Saliha Kanık Yüksek ๑ Aslınur Özkaya Parlakay ๑ Neşe Yaralı $\bullet$ Namık Yaşar Özbek ๑ Hasan Tezer $\odot$}

\section{ABSTRACT}

Objective: Febrile neutropenia (FN) is a common and life-threatening complication that develops during therapy for childhood cancer. Serious bacterial illness is a significant cause of morbidity and mortality for neutropenic patients The primary objective of the study was to determine etiology and clinical course of fever in neutropenic children with cancer. The aim was to identify the risk of development of invasive bacterial infection (IBI) and factors associated with mortality in pediatric cancer FEN patients.

Method: This study was conducted in University of Health Sciences, Ankara Child Health and Diseases Hematology Oncology Training and Research Hospital between January 2006 and and December 2013. Invasive bacterial infections and related mortality in children aged 0 to 18 years of age were documented.

Results: A total of 325 neutropenic febrile episodes of 134 patients were evaluated. The most common preexisting risk factor for invasive bacterial infection was acute myeloid leukemia phenotyp. Other risk factors included, thrombocytopenia, bloodstream infection, C-reactive protein value $>9 \mathrm{mg} / \mathrm{dL}$ and pneumoniae. In our case series overall infection-associated mortality was found as $4 \%$ similar as in the literature.

Conclusion: Invasive bacterial infections is still be major cause of mortality and morbidity for pediatric leukemia.

Keywords: Invasive bacterial infection, child, leukemia, risk factor

Öz

Amaç: Çocukluk çağı kanserlerinde tedavi sırasında gelişen febril nötropeni sık görülen ve yaşamı tehdit eden bir komplikasyondur. Ciddi bakteriyel enfeksiyonlar nötropenik olan hastalarda mortalite ve morbidite nedeni olmaktadır. Çalışmanın amacı çocukluk çağı lösemilerinde gelişen febril nötropenilerde invazif bakteriyel enfeksiyon gelişme riskini belirlemek ve mortalite ile ilişkili durumları ortaya koymaktır.

Yöntem: Çalışma, retrospektif olarak Ocak 2006-Ekim 2013 tarihleri arasında, Sağık Bakanlığı Sağlık Bilimleri Üniversitesi Ankara Çocuk Sağlığı ve Hastalıkları Hematoloji Onkoloji Eğitim Araştırma Hastanesinde yürütülmüştür. 0-18 yaş çocuk lösemi hastalarında gelişen invazif bakteriyel enfeksiyonlar ve buna bağlı gelişen mortalite dökümante edilmiştir.

Bulgular: Çalışmada, 134 hastanın 325 febril nötropeni atağı incelenmiştir. Invazif bakteriyel enfeksiyon gelişmi için en yüksek risk faktörü akut miyeloid lösemi fenotipi olarak bulunmuştur. Diğer risk faktörleri ise trombositopeni, kan dolaşım enfeksiyonu, C-reaktif protein $>9 \mathrm{mg} / \mathrm{dL}$ ve pnömoni olarak bulunmuştur. Olgu serimizde enfeksiyon ilişkili mortalite \%4 olarak bulunmuştur, bu da literatürle benzer düzeydedir. Sonuç: Invazif bakteriyel enfeksiyonlar pediatirk lösemilerde halen önemli bir mortalite ve morbidite nedenidir.

Anahtar kelimeler: Invazif bakteriyel enfeksiyon, çocuk, lösemi, risk faktör
Alındığı tarih: 18.09 .2018

Kabul tarihi: 23.10 .2018

Online Yayın tarihi: 14.03.2019

Belgin Gülhan SBÜ Ankara Çocuk Sağlığı ve Hastalıkları Hematoloji Onkoloji EAH, Çocuk Enfeksiyon Bilim Dalı, Ankara, Türkiye docbelgin@yahoo.com ORCID: 0000-0003-0839-1301

S. Kanık Yüksek 0000-0002-2538-2872 A. Ö. Parlakay 0000-0001-5691-2461

H. Tezer 0000-0001-6871-4112 SBÜ Ankara Çocuk Sağlığı ve Hastalıkları Hematoloji Onkoloji EAH, Çocuk Enfeksiyon Bilim Dalı, Ankara, Türkiye

N. Yaralı 0000-0001-5488-2385 N.Y. Özbek 0000-0001-6857-0681 SBÜ Ankara Çocuk Sağlığı ve Hastalıkları Hematoloji Onkoloji EAH, Çocuk Hematoloji Bilim Dalı, Ankara, Türkiye 


\section{INTRODUCTION}

Febrile neutropenia (FN) is a common and lifethreatening complication of therapy for childhood cancer. Although fever in healthy individuals does not always necessarily indicate severe illness, fever in patients with neutropenia may herald a lifethreatening infection. Serious bacterial infection is a significant cause of morbidity and mortality for neutropenic patients. A large proportion of the evidence of risk stratifications has been adapted from adult malignancy patients ${ }^{(1,2)}$.

Survival rates among children with cancer have progressively increased in the past decades now exceeding 75 percent. However aggressive treatment of cancer has resulted in a higher risk of infection ${ }^{(3)}$. Granulocytopenia is to be considered the main risk factor for infection. Frequently, fever is the first and the only sign that indicates the presence of infection in these children and therefore, must be considered as an indication of emergency intervention ${ }^{(4)}$.

Current knowledge indicates that children with cancer do not all have the same risk for invasive bacterial infection (IBI). According to Infectious Diseases Society of America, high-risk patients are those with anticipated prolonged ( $>7$ days) and profound neutropenia (absolute neutrophil count $\leq 100$ cells $/ \mathrm{mm}^{3}$ following cytotoxic chemotherapy) and/or significant medical comorbid conditions, including hypotension, pneumonia, new-onset abdominal pain, or neurologic changes ${ }^{(5)}$.

This study was conducted to describe the etiology and clinical course of fever in neutropenic children with leukemia. The aim was to identify the risk of invasive bacterial infection and factors associated with mortality in $\mathrm{FN}$ patients with pediatric leukemia.

\section{METHODOLOGY}

\section{Patients}

All children $\leq 18$ years of age with cancer, fever and neutropenia (absolute neutrophil count (ANC) $\leq 1500 / \mathrm{mm}^{3}$ ), admitted to a referral center in the Central Anatolia, Ankara Children Hematology \&
Oncology Education and Research Hospital, between January 1, 2006 and December 31, 2013 were evaluated.

A data sheet for evaluating each episode has been filled out including: (1) patient's age, sex, type of leukemia, underlying disease and disease stage, chemotherapy regimen of patient (initial or maintenance), (2) presence of any intravenous device, day of catheterization, (3) clinical assessment, highest axillary temperature on the first day of admission, blood pressure and signs and symptoms indicative of any clinically identifiable infectious focus (eg. presence of hypotension, fever over $39^{\circ} \mathrm{C}$, paleness, etc.) (4) laboratory test results; hemoglobin level, platelet count, ANC, absolute monocyte count (AMC), quantitative serum $C$ reactive protein (CRP (5) antifungal treatment in the last 6 months, steroid treatment in last 2 weeks (6) catheterization and peripheric blood culture results, chest $X$ ray and thorax tomography findings and clinical infection were noted.

Clinical infection category included; upper respiratory tract infection or oral cavity infection, pneumonia, urinary tract infection, soft tissue infection, typhlitis, central nervous system infection, catheterrelated bloodstream infection (CRBSI), bloodstream infection, diarrhea, sepsis and other infections.

\section{Definitions}

Febrile neutropenia was defined as a single body temperature of $>38.5^{\circ} \mathrm{C}$ or two repeated readings of $>38.0^{\circ} \mathrm{C}$ with neutropenia defined as $\leq 1500$ neutrophils $/ \mathrm{mm}^{3}$. Moderate neutropenia was defined as 500-1000 neutrophils $/ \mathrm{mm}^{3}$, severe neutropenia as $\leq 500$ neutrophils $/ \mathrm{mm}^{3}{ }^{(5)}$.

A child was considered to have invasive bacterial infection (IBI) if bacteremia was detected and/or a positive result of bacterial culture of specimen was obtained from a usually sterile site (e.g., indwelling catheter, urine, CSF), in the absence of a positive culture result if clinical and laboratory findings were strongly suggestive of a sepsis syndrome and/or focal organ involvement in a child with hemodynamic instability and severe malaise ${ }^{(6)}$.

Diagnosis of CRBSI is based on the following: The 
presence of a central venous catheter (CVC); signs of catheter insertion site infection, clinical symptoms and signs of bacteremia; resolution of the symptoms and signs of bacteremia after removal of the suspect CVC; positive blood culture; and growth of the same organism in the sample obtained from the catheter ${ }^{(7)}$.

\section{Statistical Analysis}

Comparisons of the proportion of risk factors between groups were performed using a chi-square test. Comparisons of medians between groups were performed using the Mann-Whitney $U$ test. A multivariate logistic regression analysis was used for assessment of association between significant risk factors for the occurrence of infection or mortality. Statistical significance was assigned to two-sided $p$ values less than 0.5 .

\section{Ethical issues}

The study was started after approval of the ethics committee of the hospital was obtained.

\section{RESULTS}

\section{Patients' characterics}

During the 7-years of study period, a total of 324 FN episodes in 134 patients (57 girls, 77 boys) were evaluated. The mean age of the patients at the time of enrollment was $6.6 \pm 4.5$ years (range; 6 months18 years). The number and percentage of children with specific cancer types and hematologic diseases were as follows; 105 (78.3\%) had acute Imphocytic leukemia (ALL), 23 (17.1\%) had acute myeloid leukemia (AML) and 6 (4.47\%) had hemophagocytic lymphohistiocytosis. Fifty-six (17.3\%) episodes were cases of relapse leukemia. None of the children had received a bone marrow transplant (Table 1 ).

The patients received induction chemotherapy in 247 (76.2\%) episodes. During 152 FN episodes (46.9\%), patients had history of indwelling intravenous catheter for a median duration of 61.5 days (1-767 days). Overall admission characteristics of 324 febrile neutropenia episodes are shown in Table 1.

The mean ANC at the enrollment was $236 \pm 334$ neutrophils $/ \mathrm{mm}^{3}$. A total of $273(84.3 \%)$ episodes of
Table 1. Overall admission characteristics of 324 episodes of febrile neutropenia admission characteristics.

\begin{tabular}{lc}
\hline Episodes $(\mathbf{n}=\mathbf{3 2 4})$ & Numbers \\
\hline Mean age in years & $6.6 \pm 4.5$ years \\
Male (\%) & $77(57.4 \%)$ \\
Type of cancer (\%) & $105(78.3 \%)$ \\
Acute lymphoid leukemia & $23(17.1 \%)$ \\
Acute myeloid leukemia & $6(4.47 \%)$ \\
Haemophagocytic lymphohystiositosis & $56(17.3 \%)$ \\
Leukemia relapse & $152(46.9 \%)$ \\
Use of central venous catheter $(\%)$ & $38,3^{\circ} \mathrm{C}($ range; 37.7 \\
Median temperature $\left({ }^{\circ} \mathrm{C}\right)$ & $\left.{ }^{\circ} \mathrm{C}-40.5{ }^{\circ} \mathrm{C}\right)$ \\
& 184 days \\
Mean duration between chemotherapy & $($ range $0-1097$ days) \\
initiation date and fever & $6.8 \pm 7.35$ days \\
Mean duration between last chemother- & (range $0-49$ days). \\
apy day and first day of febril neutropenic & \\
episod &
\end{tabular}

Table 2. Laboratory parameters at admission.

\begin{tabular}{lc}
\hline Parameter & Median (Range) \\
\hline Hemoglobin $(\mathrm{g} / \mathrm{dl})$ & $9.25(5.2-14.7)$ \\
Platelets $\left(/ \mathrm{mm}^{3}\right)$ & $53500(900-1302000)$ \\
ANC $\left(/ \mathrm{mm}^{3}\right)$ & $100(0-1500)$ \\
AMC $\left(/ \mathrm{mm}^{3}\right)$ & $0(0-1200)$ \\
CRP $(\mathrm{mg} / \mathrm{dL})$ & $3.68(0.01-68)$
\end{tabular}

ANC: absolute neutrophile count, AMC: Absolute monocyte count, CRP: C-reactive protein.

Table 3. The number and percentage of source of clinical infection in febrile neutropenic episodes.

\begin{tabular}{lc}
\hline Etiology & Number of episodes (\%) \\
\hline Unidentified & $89(27.5 \%)$ \\
Upper respiratory tract infection/oral & $78(24.1 \%)$ \\
cavity infection & \\
Pneumonia & $53(16.4 \%)$ \\
Gastrointestinal system infection & $26(8.0 \%)$ \\
Central venous catheter infection & $11(3.4 \%)$ \\
Blood stream infection & $11(3.4 \%)$ \\
Urinary tract infection & $13(4.0 \%)$ \\
Typhylitis & $4(1.2 \%)$ \\
Soft tissue infection & $18(5.4 \%)$ \\
Other & $21(6.5 \%)$ \\
\end{tabular}

severe neutropenia (ANC $<500$ neutrophils $/ \mathrm{mm}^{3}$ ) were detected, ANC was $\leq 100$ neutrophils $\mathrm{mm}^{3}$ in 185 (57.1\%), and 500-1000 neutrophils $/ \mathrm{mm}^{3}$ in 37 (11.4\%) episodes.

Clinical source of infection was identified in 235 episodes (72.2\%). Upper respiratory tract infection/ 
oral cavity infection was the most common source of infection and present in $23.1 \%$ of the patients and pneumoniae was detected in $15.1 \%$ of all episodes. The rest of the etiologies are presented in Table 3,4.

In 38 (11.7\%) episodes, a pathogenic microorganism was identified from peripheral vein blood cultures. The most common microorganism identified from peripheral vein blood cultures were coagulasenegative Staphylococcus spp. and Streptococcus spp. Fungal pathogen was identified in peripheral blood cultures in 5 (1.5\%) episodes (Candida crusei in 1, Candida albicans in 3, Candida spp in 1 episode).

Central venous catheter was present in 152 (46.9\%) episodes. In 38 (11.7\%) of all episodes, a pathogenic microorganism was identified in CVC and diagnosed as catheter-related bloodstream infection (CRBSI) in 13 (4\%), while the remaining 25 episodes

Table 4. Bacterial species recovered for 324 episodes of febrile neutropenic children, according to the site of the isolate.

\begin{tabular}{lccc}
\hline Isolate & Blood & Catheter & Urine \\
\hline Coagulase-negative Staphylococcus spp & 18 & 20 & \\
Klebsiella species & 4 & 4 & \\
Escherichia coli & 1 & 3 & 2 \\
Streptococcus species & 7 & 5 & \\
Acinetobacter species & 2 & 1 & \\
Enterococcus species & 1 & 2 & \\
Pseudomonas species & 2 & 2 & \\
Enterobacter cloaca & 2 & 1 & \\
Stap hominis & 1 & - & \\
Total & 38 & 38 \\
\hline
\end{tabular}

was considered as bacterial colonisation. The rate of CRBSI in catheterized patients was found as $8.5 \%$. The pathogenic microorganisms identified were as follows in CRBSI; in 4 case (30.7\%) non-albicans candida spp (2 Candida crusei, 1 Candida tropicalis, 1 unknown), in 4 (30.7\%) coagulase-negative Staphylococcus, in 2 (15.3\%) Candida albicans, in 2 (15.3\%) Klebsiella spp and in 1 (7.6\%) Streptococcus pneumoniae.

S. Pneumoniae was present in 53 (16.4\%) episodes. 7 (13.2\%) of 53 patients with pneumonia died. Possible IAP had been identified in 2 of 7 fatal pneumonia episodes. Most of the pneumonia infection was observed in patients recieving maintenance chemotherapy ( $n=30,56.6 \%, p=0.002)$ and in $16(30.1 \%)$ patients recurrent/progressive pneumonia was detected. The remaining 6 episodes of pneumonia were observed in patients at the admission of hospital before initiating any chemotheraphy regimen at the enrollment phase of leukemic patients.

Pathogenic microorganisms that were detected in bloodstream infections were as follows; Candida spp in 2, Streptococcus spp in 2, Pseudomonas aeurigino$s a$ in 1, coagulase-negative Staphylococcus in 2, Klebsiella spp in 1 episode. The patient with Pseudomonas aeuriginosa-related bloodstream infection had died.

Invasive bacterial infection was detected in 138 (44.8\%) of total of 324 episodes. Invasive bacterial

Table 5. General description of the 13 children who died during the febrile neutropenic episode.

\begin{tabular}{lccccccc}
\hline No & Age & Gender & Cancer type & ANC & Therapy & Clinic infection & Microorganism/source \\
\hline 1 & 2 & $\mathrm{~F}$ & ALL/remision & 440 & Maintenance & Pneumonia & None \\
2 & 13 & $\mathrm{M}$ & MDS/relaps & 500 & Intensive & Pneumonia & None \\
3 & 15 & $\mathrm{M}$ & AML/relaps & 0 & Intensive & Pneumonia & None \\
4 & 15 & $\mathrm{~F}$ & MDS/relaps & 0 & Intensive & Pneumonia & None \\
5 & 1,5 & $\mathrm{E}$ & HLH/relaps & 0 & Intensive & Pneumonia & None \\
6 & 1 & $\mathrm{E}$ & HLH/relaps & 0 & Intensive & Pneumonia & None \\
7 & 3 & $\mathrm{E}$ & AML/relaps & 500 & Intensive & Pneumonia & Klebsiella spp \\
8 & 10,5 & $\mathrm{~F}$ & AML/relaps & 500 & Intensive & CRBSI & Pseudomonas spp \\
9 & 18 & $\mathrm{M}$ & AML/relaps & 0 & Intensive & Bloodstream inf. & Candida albicans \\
10 & 5 & $\mathrm{M}$ & ALL/relaps & 0 & Intensive & Bloodstream inf. & Klebsiella spp \\
11 & 2 & $\mathrm{M}$ & ALL/relaps & 0 & Intensive & Bloodstream inf & Klebsiella spp \\
12 & 11.5 & $\mathrm{~F}$ & ALL/relaps & 0 & Intensive & Bloodstream inf & Coagulase negative staphylococcus spp \\
13 & 1 & $\mathrm{M}$ & ALL/relaps & 0 & Intensive & URTI/Oral cavity infection & Coaplas
\end{tabular}

F: Female, M: Male, ANC: absolute neutrophil count, ALL: acute Imphocytic leukemia, AML: Acute myeloid leukemia, MDS: myelodysplastic syndrome, HLH: Hemophagocytic lymphohistiocytosis, CRBSI: catheter related bloodstream infections, URTI: urinary tract infectionb 
infection was more frequently observed in AML patients $(p=0.024)$. Thrombocytopenia (mean platelet $70494 \pm 68832 / \mathrm{mm}^{3}$ ) was more frequently detected in invasive bacterial infection group $(p=0.034)$. Invasive bacterial infection was higher in CRP $>9 \mathrm{mg} /$ $d L$ group $(p=0.03$ ).

Mortality was observed in 13 (9.7\%) of 134 patients and $4 \%$ in 324 febrile neutropenic episodes. In leukemia group, mortality rate was higher in $\mathrm{AML}$ patients compared to ALL $(p<0.001)$.

Clinical diagnoses of fatal patients were as following; pneumonia was detected in 7 (53.8\%), bloodstream infection in $3(23 \%)$, catheter-related bloodstream infection in 1 (7.69\%), gastrointestinal system infection in 1 (7.69\%), oral cavity infection in 1 (7.69\%) patient. Mean age of the children who died was $7.57 \pm 6.3$ (range $1-18$ years) years, 8 of 14 patients were male. Relevant demographic, clinical, and laboratory findings for these 13 children are described in Table 5.

Overall infection-associated mortality is found as $4 \%$. In our cases, early clinical and laboratory factors significantly associated with death were presence of leukemia type of AML ( $p=0.01)$ and invasive bacterial infection $(p=0.038)$. Mortality was higher in patients with pneumonia and bloodstream infection $(p=0.002)$.

\section{DISCUSSION}

We present a series of 324 of FN episodes with an overall infection-associated mortality of $4 \%$. In our cases, early clinical and laboratory factors significantly associated with death were presence of $A M L$ and invasive bacterial infections.

Early reports on the epidemiology of bacterial infections showed gram-negative pathogens as the major cause of infection in neutropenic children and adults. Escherichia coli, P. aeruginosa, and Klebsiella spp. were the most commonly isolated pathogens ${ }^{(8)}$. Subsequently, toward the end of the 1980s, grampositive pathogens were being increasingly recognized as an important source of FN ${ }^{(9)}$. This shift in pathogens could be due to increased use of central venous catheters, increased prevalence of mucositis, prophylactic regimens with predominantly gramnegative activity and increases in mucositis- specific pathogens such as viridans streptococci ${ }^{(10)}$. The most common species identified in children with high risk febrile neutropenia and sepsis are E. coli, S. aureus, and $P$. aeruginosa concordant with our results ${ }^{(6)}$.

Catheter-related bloodstream infection is the most common complication of catheterization . Hakim et al. ${ }^{(11)}$ investigated $337 \mathrm{FN}$ episodes in children and in $86(25 \%)$ episodes they had demonstrated infection and probable infection was detected in 75 episodes (22\%). The most frequently isolated organisms were determined as viridans streptococci ${ }^{(13)}$, Pseudomonas spp (6) and E. coli (6) Afzal et al. (12) studied 425 pediatric ALL patients and the most common organisms identified were coagulase negative Staphylococcus $(11 / 85,12.9 \%)$, viridans group Streptococcus (11/85, 12.9\%), Staphylococcus aureus $(10 / 85,11.8 \%)$. We detected coagulase negative Staphylococcus commonly in catheter and blood cultures (4 in 13 CRBSI) similar to Afzal et al. But in our cohort candida species were the most common microorganism ( 6 in 13 CRBSI). The mean of catheter day in candida species associated CRBSI detected patients was 111.4 days (21-194 days). The mean duration of catheterization in all CRBSI positive patients was 65.9 days (2-194 days). Increase in catheter dwell time could be associated with candida related infection in our patients. All of our patients were severely neutropenic and had hematologic malignancy and also increase in catheter dwell time was observed in our patients ${ }^{(13)}$.

In our study pneumonia was detected in 53 (16.4\%) episodes. Seven (13.2\%) patients with pneumonia died in our case series. Tezcan et al. ${ }^{(14)}$ evaluated 621 episodes of febrile neutropenia in pediatric patients and detected 425 infections in 345 episodes. They found that pneumonia was the most common infection $(90 / 425 ; 32.7 \%)$.

We especially evaluated invasive bacterial infection and risk factors for developing IBI in febrile neutropenic patients. According to our study AML phenotype, thrombocytopenia, bloodstream infection, and pneumonia was associated with IBI. Because mortality was observed in only IBI patient in our case 
series. Santolaya et al. ${ }^{(6)}$ investigated risk factor for $\mid \mathrm{BI}$ and febrile neutropenia. They had observed CRP, hypotension, relapse of leukemia, lower platelet counts and recent receipt of chemotherapy. They suggested that identification of these 5 risk factors during the first $24 \mathrm{~h}$ of hospitalization was helpful in discriminating between children with a high or low risk for invasive bacterial infection (IBI). We did not find any statistical relation between IBI and chemotherapy regimen, or time interval between chemotherapy and FN episodes.

When microbiologically or clinically documented infections experienced by pediatric patients with FEN were investigated, documented infection is less commonly observed in children compared to adults with a frequency of $40-50 \%{ }^{(18)}$. We identified bacterial and fungal microorganisms in only 20 (14.4\%) invasive bacterial infection positive episodes. Bacterial isolation technique using conventional microbiologic techniques have rarely identified microbial agents in more than $25 \%$ of children with clinical signs and laboratory findings, suggesting a high risk for an invasive bacterial infection ${ }^{(6)}$. We found mortality rate in our patients as $4 \%$. All deceased patients were at high risk for invasive bacterial infections. Mortality associated with febrile neutropenia in cancer patients ranges from $2-6 \%$ in children ${ }^{(16,17)}$. Santolaya et al. ${ }^{(18)}$ investigated clinical and laboratory factors associated with death in children with cancer and febrile neutropenic episodes. They found factors significantly associated with death as relapse of ALL, hypotension, diagnosis of sepsis, ANC 100/ $\mathrm{mm}^{3}$, AMC 100/mm $\mathrm{mm}^{3}$ BUN $18 \mathrm{mg} / \mathrm{dL}$, CRP $90 \mathrm{mg} / \mathrm{L}$, and positive cultures. They found the most common pathogens as E. coli, S. aureus, P. aeruginosa and Klebsiella species. Two longitudinal studies performed by the University Health System Consortium in the United States provided information for both adult and pediatric populations. The most important independent risk factors for death were presence of an invasive fungal infection, Gram-negative or Grampositive bacteremia, pneumonia, and/or comorbidity factors ${ }^{(19)}$. In our cases, early clinical and laboratory factors significantly associated with mortality were presence of AML $(p=0.01)$ and presence of invasive bacterial infection ( $p=0.038)$. Mortality was higher in patients with pneumonia and bloodstream infection $(p=0.002)$. Two of 13 patients died because of IAP.

\section{CONCLUSION}

AML phenotype, thrombocytopenia, bloodstream infection, CRP value $>9 \mathrm{mg} / \mathrm{dL}$ and pneumonia were associated with IBI according to our study. We found mortality rate in our patients as $4 \%$ similar as in the literature and in our cases, early clinical and laboratory factors significantly associated with death were presence of AML $(p=0.01)$ and invasive bacterial infection $(p=0.038)$.

The study has several limitation. The study was a retrospective trial and the duration of neutropenia could not be determined which is also an important factor for IBI.

The authors have no conflicts of interest relevant to this article.

\section{REFERENCES}

1. Santolaya $M E$, Alvarez AM, Avilés $C L$, Becker $A$, Venegas $M$, O'Ryan M, et al. Early hospital discharge followed by outpatient manage- ment versus continued hospitalization of children with cancer, fever, and neutropenia at low risk for invasive bacterial infection. J Clin Oncol. 2004;22:3784-9. https://doi.org/10.1200/JCO.2004.01.078

2. Anoop P, Anjay MA. Febrile neutropenia: transition towards a risk-directed approach. Arch Dis Child. 2007;92:467-8.

3. Reilly A. Infections in children with cancer-old approaches and new. Eur J Cancer. 2003;39:652-3. https://doi.org/10.1016/S0959-8049(02)00799-2

4. Mousset S, Buchheidt D, Heinz W, Ruhnke M, Cornely OA, Egerer $\mathrm{G}$, et al. Antimicrobial therapy of unexplained fever in neutropenic patients. Guidelines of the Infectious Diseases Working Party (AGIHO) of the German Society of Hematology and Oncology (DGHO), Study Group Interven- tional Therapy of Unexplained Fever, Arbeitsgemeinschaft Suppor- tivmassnahmen in der Onkologie (ASO) of the Deutsche Krebsgesellschaft (DKG-German Cancer Society). Ann Hematol. 2003;82:105-7.

5. Freifeld AG, Bow EJ, Sepkowitz KA, Boeckh MJ, Ito JI, Mullen $C A$, et al. Clinical practice guideline for the use of antimicrobial agents in neutropenic patients with cancer: 2010 update by the Infectious Diseases Society of America. Clin Infect Dis. 2011;52:56-93.

https://doi.org/10.1093/cid/cir073

6. Santolaya ME, Alvarez AM, Aviles $C L$, Becker A, King A, Mosso $C$, et al. Prospective, multicenter evaluation of risk factors associated with invasive bacterial infection in children with cancer, neutropenia and fever. J Clin Oncol. 
2001;19:3415-21. https://doi.org/10.1200/JCO.2001.19.14.3415

7. Ingram J, Weitzman S, Greenberg ML, Parkin F, Filler R. Complications of indwelling venous access lines in the pediatric hematology patient: a prospective comparison of external venous catheters and subcutaneous ports. Am J Pediatr Hematol Oncol 1991;13:130-6.

https://doi.org/10.1097/00043426-199122000-00003

8. Singer C, Kaplan $\mathrm{MH}$, Armstrong D. Bacteremia and fungemia complicating neoplastic disease: a study of 364 cases. Am J Med 1977;62:731-42. https://doi.org/10.1016/0002-9343(77)90876-2

9. Viscoli C, Van der Auwera P, Meunier F. Gram-positive infections in granulocytopenic patients: an important issue. J Antimicrob Chemother 1988;21:149-56. https://doi.org/10.1093/jac/21.suppl_C.149

10. Zinner SH. Changing epidemiology of infections in patients with neutropenia and cancer: emphasis on gram-positive and resistant bacteria. Clin Infect Dis 1999;29:490-4. https://doi.org/10.1086/598620

11. Hakim H, Flynn PM, Knapp KM, Srivastava DK, Gaur AH. Etiology and Clinical course of febrile Neutropenia in children with cancer. J Pediatr Hematol Oncol 2009;31:623-9. https://doi.org/10.1097/MPH.0b013e3181b1edc6

12. Afzal S, Ethier MC, Dupuis LL, Tang L, Punnett AS, Richardson $\mathrm{SE}$, Allen $\mathrm{U}$, et al. Risk factors for infection-related outcomes during induction theraphy for childhood acute lymphoblastic leukemia. Pediatr Infect Dis J. 2009;28:1064-8. https://doi.org/10.1097/INF.0b013e3181aa6eae

13. Mermel LA, Allon M, Bouza E, Craven DE, Flynn P, O'Grady NP, et al. Clinical Practice Guidelines for the Diagnosis and
Management of Intravascular Catheter-Related Infection: 2009 Update by the Infectious Diseases Society of America. Clinical Infectious Diseases. 2009;49:1-5. https://doi.org/10.1086/599376

14. Tezcan G, Kupesiz A, Ozturk F, Ogunc D, Gultekin M, Yesilipek $A$, et al. Episodes of fever and neutropenia in children with cancer in a tertiary care medical center in Turkey. Pediatric Hematology and Oncology. 2006;23:217-29. https://doi.org/10.1080/08880010500506719

15. Talcott JA, Finberg R, Mayer RJ, Goldman L. The medical course of cancer patients with fever and neutropenia. Arch Intern Med. 1988;148:2561-20. https://doi.org/10.1001/archinte.1988.00380120031007

16. Rackoff WR, Gonin R, Robinson C, Kreissman SG, Breitfeld PB. Predicting the risk of bacteremia in children with fever and neutropenia. J Clin Oncol. 1996;14:919-24. https://doi.org/10.1200/JCO.1996.14.3.919

17. Basu SK, Fernandez ID, Fisher SG, Asselin BL, Lyman GH. Length of stay and mortality associated with febrile neutropenia among children with cancer. J Clin Oncol. 2005;23:795866. https://doi.org/10.1200/JCO.2005.01.6378

18. Santolaya ME, Alvarez AM, Avilés CL, Becker A, Mosso C, O'Ryan $M$, et al. Admission clinical and laboratory factors associated with death in children with cancer during a febrile neutropenic episode. Pediatr Infect Dis J. 2007;26:794-8. https://doi.org/10.1097/INF.0b013e318124aa44

19. Kuderer NM, Dale DC, Crawford J, Cosler LE, Lyman GH. Mortality, morbidity, and cost associated with febrile neutropenia in adult cancer patients. Cancer. 2006;106:2258-66. https://doi.org/10.1002/cncr.21847 